\title{
Prophecy of Private Label Branding in India
}

\author{
R.Nagarajan, Dr. S.Chandrachud \\ Research Scholar, Rayalasema University \\ Faculty of Economics, VELS University
}

\begin{abstract}
India is enduring with migration of unorganized to organized retailing in the form of a new structural framework through manufacturing of consumer products in the name of private label branding. The current private label market espoused nearly 13 billion rupees in Indian retail, contributing more than 10 percent of organized retail. The current study focus on reasons for the structural transformation of Indian retails towards private label branding and prophecy of private label in Indian context. Initial chapter briefs about the basic information about the private label branding and organizational break up of Indian retail. Chapter two enrolls the literature review. Chapter three envisages the vicious circle of private labeling. Chapter four depicts the vicious circle of private labeling and final chapter insight prophecy of Private label branding in India.
\end{abstract}

\section{INTRODUCTION}

Different authors have defined the term private label brand in different ways. The meaning of private label branding is the supply of goods or services to the consumer by the retailers with their own brand name even though those goods or services are manufactured or provided by other manufacturer or service provider. The efficacy of Indian retail sector has witnessed myriad growth in private labeling in the recent past. This is mainly due to focus of selected business group like Aditya Birla, Reliance, Spencer and others, towards the private label retailing. The twin effects, the foreign policy of the Indian government on both multi-brands and single brand in retail sector and growth of global private labeling influenced the Indian retailers to show more interest on the private labeling. Even though the strategy of private labeling new to Indian retailing, it has been introduced in western side and Europe, more than 3 decades. The liberalization era of India has delivered a spectrum of foreign policy with the start up of the new industrial policy 1991. The international agreement on trade and services in 1995, the world trade organization (WTO) has included not only the wholesale trade but also the retail trade. After two years, GOI has permitted the Foreign Direct Investment (FDI) in cash and carry the wholesale business under government approval with cent percent rights. Later, i.e., from 2006 approval becomes automatic. In the same year, up to 51 percent investment is permitted for single brand retail outlets which have been declared into cent percent of FDI during 2011. In 2013, the GOI has relieved the foreign investment rules in retails from restriction, in order to attract global supermarket chains. On the other hand, the centre of attraction for the global retail trade is the private label branding, famously known as 'Phantom branding'. India has become the fifth best destination for the retail market at universal level of trading. Indian retail market gains its importance as it contributes nearly 15 percent of GDP. The projected value of Indian retail market, at the end of the year 2016 is 490 US dollars at a Compound annual growth rate of 7 percent which may reach more than 900 US dollars by 2024.The Indian retail market consists of both organized retailing and unorganized retailing. Those retailers who are filed returns under sales tax and income tax are called licensed retailers nearly 16 percent and rests of them are unorganized retailers approximately 84 percent

The organized or licensed retailers include hypermarkets, modern retail outlets, super markets and corporate supported retail outlets etc. Nevertheless, the majority of retail industry is in the hands of the unorganized retailers like local kirana shop, Nadar shop, owner-operated general stores, hand carts, pushcart and street vendors. 


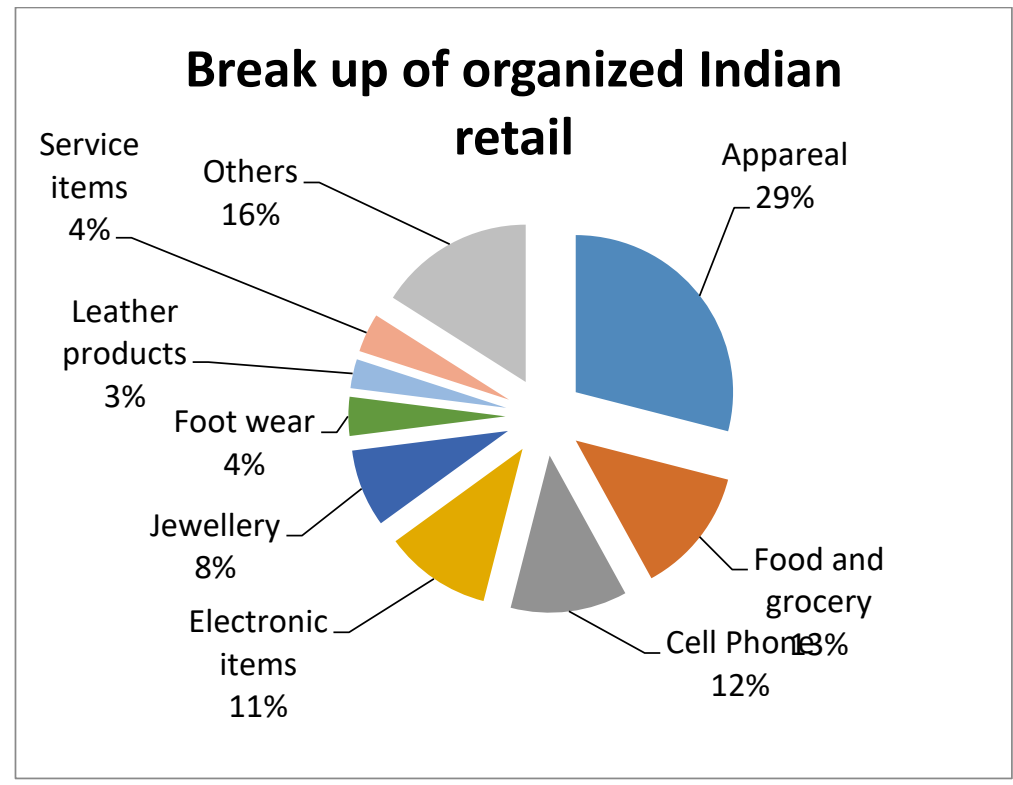

The Back bone of the organized Indian retail is the private label branding. The lion share of organized retail trade contributed by the store branding. The consumption patterns of the ideal customers are also slowly changing due to social, economical, political, cultural and technical changes. Therefore, the main reasons for the structural changes in the Indian retail trade are: Firstly, encouragement of Government through foreign policy and secondly the interest of modern retailer on private label branding. Finally, the mechanism of the private label branding and its conceptual framework implemented as an arena of successive dosages in India.

\section{Literature Review}

1. Paul Samuelsson (1938). The classical theory of consumer behavior is the revealed preference theory. He described the concept of behavior with preference pattern of the ideal customer. For the research about the demand for the private label items, the axiom of revealed preference theory are used as it exhibits that the purchasing habits of the individuals are the key factor to reveal the preference of them.

2. The book on Retail management - Principles and Practices, edited by R. Sudarshan.(2007). The author specified that the retail sector has reached a critical stage as stores in modern formats have emerged in even in II tier and III tier cities. However the major volume of sales are still under traditional retail ways.

3. John Fernie and Leigh Sparks, (2007) he their book, expressed that the current status of retail sector envisages many challenges and these challenges are to be faced by the marketing strategy, supply chain management techniques. Secondly, private label branding is considered to be the right method to improve the modern retailing outlets.

4. Nirmalya Kumar and Jan-Benedict E.M,(2007) in their book, they analyzed how to face the challenges of store branding, particularly the strategy of private labeling.

5. Ralph Blessing (2009) in his article he explained the stages of developing the private label and Major key factors for private label branding.

6. Anupam Narula (2010), in her research findings, Many of the buyers feel there is a difference in the quality of the products which comparing the national and private brands as the modern retail outlets are providing special attention for store brands and the actual manufacturers has given up the contact with ultimate consumer.

7. Chandrachud .S, (2012)in his research article, the impact of FDI in the organized retailing in India is clearly pronounced, as the need for the hour to implement the private labeling in the modern retail outlets.

8. Chandrachud . S, (2012) in his research article, has expressed the current status of Indian retail sector by answer the question, why India is facing problem in implementing the FDI in retail sector.

9. Kalpana Singh, (2014), in her article, the current status of Indian retail sector are discussed and she answered for the question. what are the opportunities and challenges are prevailing in Indian retail industries?

10. Jubin Mehta, (2015)in his research article expressed the evolution of modern retail outlets and their initial funding with marketing strategy, Particularly, Big Basket, DogSpot, MyNutraMart etc

11. Andres Cuneo et al.(2015) in their research article, expressed the measurement of growth in the private label. They also analysed the retail distribution structure, typology and methodology of private label brands. 
12. Naimi K. Shapiro, (2016), in his articles, he listed out both the advantages and disadvantages of private label branding.

13. Knight Frank (2016) The Indian retail sector has witnessed the structural changes in the recent past as it concentrates the on private brands rather than the national brands. The promotion mix of private branding influenced by telemarketing with the information and communication gadgets through search engines, electronic mailing, mobile phones and televisions

14. Osman M Zain and M.B.Saidu (2016)There are three factor in retailer's brand influencing the customer, Product satisfaction, Product risks and Product quality

15. John Quelch and David Harding (1996) The twin reasons of retailer's overreaction are firstly the power of the private label varies with economic conditions and National brand has been challenged through consumer packaged goods

16. According to India Brand Equity Foundation report of January 2016, the total outlay of Indian retail sector is 600 billion US dollars. Due to private labeling it may reach 1300 billion (1.3 trillion)

\section{Vicious circle of private label brands}

Under customer relationship strategy the modern retailers start the private label branding with the good price offer to the prospective customer in order to attract and promote the sale of private label items. Due to this offer price, the ideal customer will be attracted and induced to migrate from national brand to store brand. When the number of customers is increasing for the private labeled product, there are new entrants in the retail sector to focus on the private label products which in turn there will be more contract of between the Modern retailers and manufacturers for supplying the phantom brand to well furnished shelves of the modern retail outlets. Once the retailers become price maker, they have an effective control over the private labeled brand products which may pave way to provide new products at the reasonable price. Once again the modern retails may offer good price to the customer for the private labeled brand items.

The vicious circle (Fig A). generates more and more new PLB items in the retail sector which gives room for the tremendous growth for the retail trade and globally, India becomes right place for retail trade. Based on the same logic, a vicious circle for retail trade also created to understand the growth in the sector.

\section{Vicious circle of Indian retail trade.}

The vicious circle of Indian retail trade starts with arrival of new customer as the PLB retailers offer good price. Those customers specified their preference on the PLB item which leads to more number of modern retail outlets not only in the first tier cities but also in the II and III tier cities of India. Due to this, there will be new entrants in the retail trade with the phantom brand with more number of business contracts with manufacturers and third parties. As a result, the Indian retail is enjoying with new variety of products under PLB production. More variety of products are available with the new vender and new design the price strategy give rise to offering price for the ideal customer by the modern retail outlets. Once again the modern retails may offer good price to the customer for the private labeled brand items. (Fig. B)

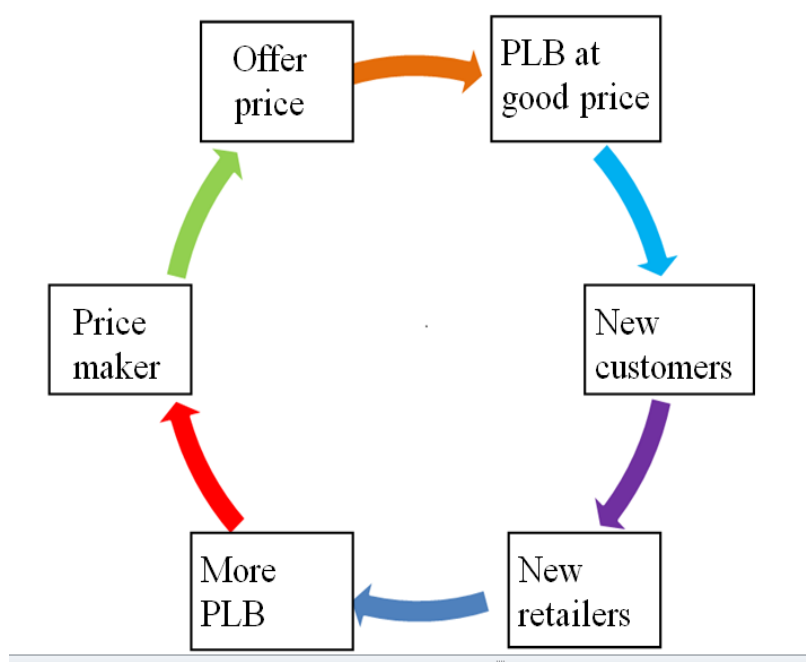

Fig. A

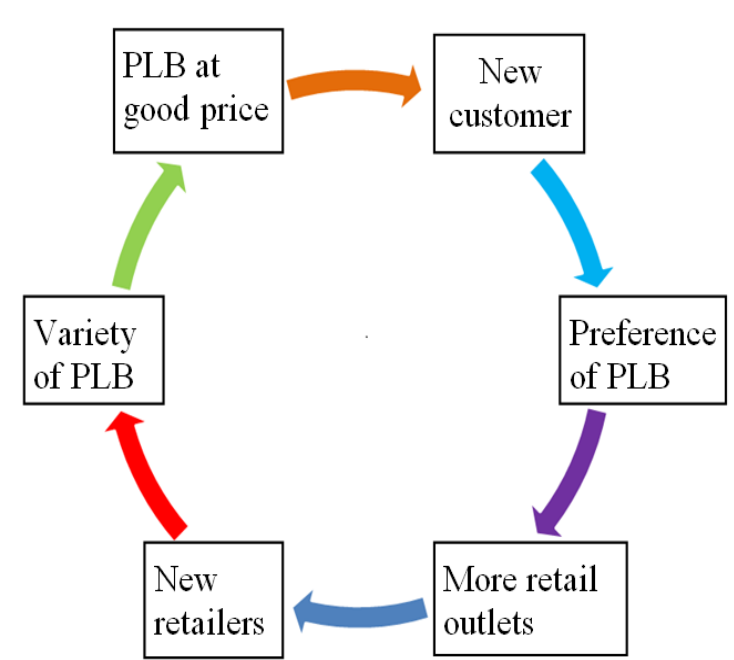

Fig. B 


\section{Reasons for sustainable growth the private label brand in India}

The Private label brand in India has witnessed a tremendous growth in Indian retail market due to several reasons.

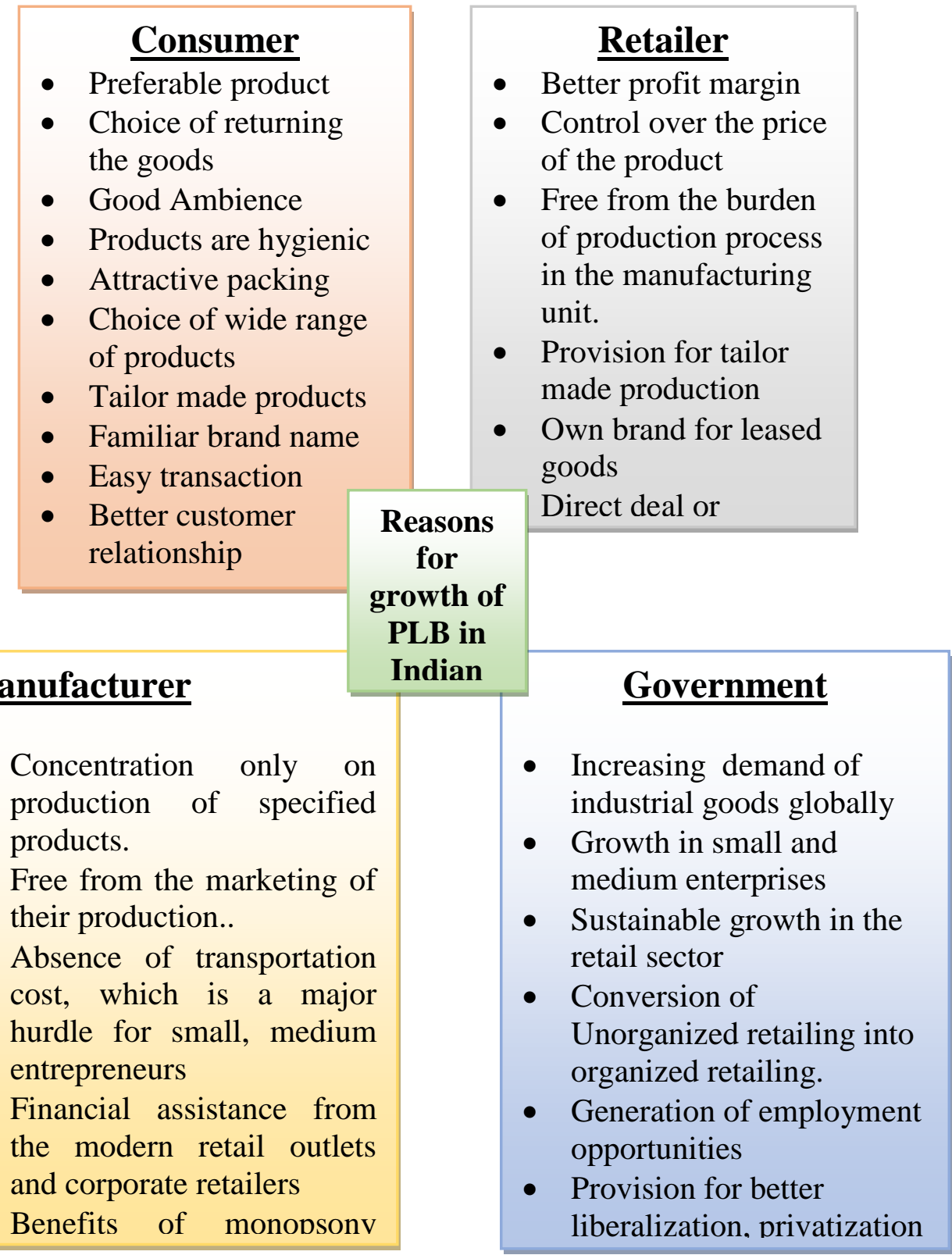

Basically, all the PLB items are well packed and aligned beautifully in the shelves of the modern retail outlets. The attitude of the ideal customers of food and grocery items has changed. They are not interested in bargaining the price of the product due to their illusory status. They feel inconvenient to stand in the platform shop and they do not want to stand in public place with the carry bag. The details of the product are displayed in the PLB packed items which are absent in local shops. People are keep on migrating from rural area to urban area for their livelihood in turn for sophistication and working hours of the public with their profession are also encourage the PLB market. These reasons are emerged from the consumer side. Better profit margin, Control over the price of the product, burden of production process in the manufacturing unit, tailor made products and direct deal with the ideal customer and uninterrupted supply of goods are main reasons for retailers interest towards private label branding. In actual manufacturer's view, they can concentrate only on production of commodities, free from the problem of marketing their product, absence of transportation cost, financial assistance from retailers, benefit of monopsony market condition and targeted profit out of business. 


\section{CONCLUSION}

The production is meaningful only when consumption is made. The Private label branding stands guarantee for the statement. Day by day, the growth of private label brand in India is flourishing. If it is continued, then what will be the position of Indian retail sector in the next decade? Answer for this question is subject to discussion as it has both positive and negative effects. The gain of economic value through private labeling will be compensated by loss of social and ethical value of the public. Even though, majority of Indian retailers are in unorganized sector, the Indian retail sector are growing in sustainable way. The subsequent doses of private label branding may disturb, not only the retail sector which in turn the entire economy. In economic terms, "Indian retail market slowly becomes oligopoly market as the entire retail transactions will be with the few hands of corporate giants who are so called modern retailers in near future". A few smart companies of modern retailers may emerge in India, modernized version of East India Company which may act as a price leader for the entire economy and they will rule Indian retail market. In spite of all these prophecy, it is evident that India is the right location for all types of business.

\section{REFERENCE}

[1] Anupam Narula, 'The battle for brands in a world of private label' Deloitate University Press, 2010, www.dupress.deloitte.com

[2] Andres cuneo, Sandra J. Milberg, Jose Migual Benavente and Javier Palcios - Frnech " The Growth of Private Label Brands: A Worldwide Phenomenon? Jounal of Invernational marketing, Volume 23, Issue 1, March 2015

[3] Chandrachud. S, 'The changing pattern of organized retailing in India', FDI in India - Issues and Challenges, pp 179-182, 2012, ISBN 81-88023-11-6

[4] Chandrachud .S. 'Current status of Indian retail sector' - Foreign Direct investment in Retail Trade in India - pp 219-224, 2014, ISBN 978-81-910561-6-

[5] IBEF report, India Brand Equity Foundation - Retail - January 2016

[6] John Fernie and Leigh Sparks, Logistics and retail management, edited book on 'emerging issues and New challenges in the retail supply chain, 2009

[7] John Quelch and David Harding, Brands Versus Private Labels: Fighting to win, Harvard Business Review, 1996

[8] Jubin Metha, 'Is private label the way to go for e-commerce companies to turn profitable'www.mystory.com June, 2015

[9] Kalpana Singh, "Retail sector in India: Present scenario, Emerging opportunities and Challenges", Volume 16, Issue 4 and Version I, IOSR journals (April 2014) pp 72-81.

[10] Michael Pepe, 'The Impact of Private Label sales Penetration on Category Profitability' - Journal of Business and Economic Research - Volume 10, Number 9, September 2012.

[11] Naomi K Shapiro, '10 Advantages of Private Label Branding' - the Retail intelligence march 2016, www.upstream.com

[12] Nirmalya Kumar and Jan-Benedict E.M, Book on 'Private Label Strategy: How to meet the Store Brand Challenge, Harvard Business School Press, Boston, Massachusetts, 2007, ISBN 10:1-4221-0167-3

[13] Osman M. Zain and Mohammed Bashir Saidy, 'The customer satisfaction on Retailer's Brand Products: A Study on Selected Areas in Klang Valley' Procedia Economics and Finance, Volume 35, 2016, Pages $418-427,7^{\text {th }}$ International Economics and Business Management Conference, (IEBMC 2015)

[14] PWC report, "Retail Sector: Global and Mexican highlights of the supermarket \& hypermarket industry" (2015)

[15] Ralph Blessing (2010) Research article on "The Evolution of Private Brands" Gfk Custom Research North America, www.greenbook.org

[16] Samuelson P. "A Note on the Pure theory of consumers' Behaviour" Economica. 5(17) 61-71 (1938)

[17] R. Sudarshan, "Retail management - principles and practices", Hard back media - first edition, 2007, ISBN 9788177081480. 